\title{
Legítima defesa, vingança privada e providência: as faces da justiça em "Os irmãos Dagobé" de Guimarães Rosa
}

\section{Gustavo de Mello Sá Carvalho Ribeiro ${ }^{1}$}

Resumo: Dos principais temas presentes na obra de Guimarães Rosa, o da justiça foi elaborado de maneira muito peculiar e permanece atual ainda hoje. No espaço sertanejo da maioria das histórias escritas por ele, não há a presença do Estado e a justiça é realizada pelas próprias personagens ou pela providência divina. O cerne deste trabalho é verificar a construção de tal tema no conto "Os irmão Dagobé" de Primeiras estórias, livro de narrativas curtas publicado em 1962. Interessa averiguar também se o tratamento dessa matéria se coaduna com o ambiente sócio-histórico representado na composição. Para tanto, partimos da análise de elementos narrativos, como a história, o narrador, as personagens e o espaço social, com base nos postulados de Genette em $O$ discurso da narrativa, para observar como essas categorias constroem o tema em pauta. Finalmente, conclui-se que a ausência do Estado no espaço rural de Minas Gerais, onde acontece a história, leva as personagens a fazerem justiça pelas próprias mãos em busca de vingança, em legítima defesa, e que, nesse percurso, temos uma ação providencial que leva a paz ao espaço representado através da inversão da lei do mais forte. O embasamento teórico do trabalho, além da obra estruturalista já citada, consiste na crítica sobre nosso corpus como, por exemplo, Lugar do mito de Ana Paula Pacheco. Além disso, lançamos mão de teorias filosóficas e jurídicas da justiça, como Filosofia do direito, de Paulo Nader.

Palavras-Chave: Literatura brasileira. Guimarães Rosa. Justiça.

Ta obra de Guimarães Rosa, o Estado, detentor legítimo do
poder de promover a justiça, quase não aparece, e a justiça surge desdobrada em duas faces: a de mão própria, realizada pelo indivíduo para assegurar um direito que julga ter, e a divina, vista como a providência de Deus. Aliás, esse é, justamente, um dos motivos da disseminação da

\footnotetext{
1 Professor substituto de literatura portuguesa na UFRJ, pesquisador de pós-doutorado na UFSCar e Doutor em Estudos Literários pela UNESP de Araraquara-SP.
} 
violência no sertão: a ausência do Estado nos logradouros afastados das cidades maiores.

As histórias de Sagarana, primeiro livro publicado pelo escritor mineiro, ambientam-se na Primeira República, quando imperava o coronelismo que, segundo Boris Fausto (2014, p. 149, grifo nosso), era uma relação contida no clientelismo que já marcava o país desde os tempos coloniais, em que os coronéis eram detentores de bases locais de poder: "[...] essa relação resultava da desigualdade social, da impossibilidade de os cidadãos efetivarem seus direitos, da precariedade ou inexistência de serviços assistenciais do Estado, da inexistência de uma carreira no serviço público.. Dentre os direitos de que o cidadão era privado nesse período, está o do acesso à justiça estatal. Como bem assinala o historiador, o que acontecia na República Velha era reflexo da herança colonial com que o Brasil sofria - e, em certos pontos, ainda hoje sofre. Por isso, embora as Primeiras estórias, de 1962, estejam localizadas num momento posterior ao dos contos de Sagarana, os espaços onde as histórias se desdobram são lugares que não se desenvolveram economicamente e permaneceram muito similares àqueles da época da antiga República.

Vemos também, nos contos rosianos de modo geral, o descrédito da instituição judiciária, seu afastamento do espaço onde se passam as histórias. Os membros da comunidade - representados pelas personagens - resolvem, individualmente, seus litígios por meio da justiça de mão própria, que é mais próxima, culturalmente mais acessível e, além de tudo, mais rápida. Portanto, podemos aproximar o que ocorre, em regra, nos contos de Guimarães Rosa o que Boaventura de Sousa Santos (2015, p. 30) aponta como tipo de justiça popular identificada "[...] como forma de suprir a carência na atuação estatal em algumas áreas dos territórios.”

Nessa esteira, Lévi-Bruhl (2010, p. 14), ao analisar o pensamento de Savigny e seus discípulos da Escola Histórica do Direito, afirma que "Cada comunidade elabora seu próprio direito, e este se exprime adequadamente 
em costumes que, melhor que as leis, lhe traduzem as exigências, as aspirações profundas ${ }^{2}$."

Essa manifestação da justiça está disseminada em toda a obra rosiana. Outro exemplo possível de ser tomado é "Corpo fechado" de Sagarana, conto em que se vê uma sociedade regida por normas dos chamados valentões. De maneira mais complexa, em Grande sertão: veredas, encontrase um sistema normativo convencionado pelos jagunços, que são regidos "[...] por um código bastante estrito, um verdadeiro bushidô, que regula a admissão e a saída, os casos de punição, os limites da violência, as relações com a população, a hierarquia, a seleção do chefe" (CANDIDO, 2006, p. 120).

Flávia Lages de Castro (2011, p. 4) ensina que o Direito, como produção humana, é cultura e, sendo cultura, “[...] é produto histórico no qual a sociedade que o produziu ou produz está inserida [...], se parece com a necessidade histórica da sociedade que o produziu; é, portanto, uma produção cultural e um reflexo das exigências dessa sociedade." Por isso, Candido (2006, p. 117) afirma que o sertão condiciona a rudeza dos jagunços, obrigando-os a criar uma lei própria para seu grupo, diferente daquela das grandes cidades, onde o Estado se faz mais presente. Se partirmos do pressuposto de que qualquer conjunto de normas e regras em uma sociedade é considerado direito, podemos afirmar que todas as comunidades humanas produziram e produzem direito (CASTRO, 2011, p. 7).

\section{Aspectos gerais das Primeiras estórias}

2 Lévi-Bruhl ressalta ainda que, em nenhum momento, Savigny ignora que há leis e normas que interligam todas as nações, mas sua teoria abalou muito as doutrinas mais espiritualistas. O mais interessante é que, em Guimarães Rosa, encontramos as duas formas de se ver a justiça em harmonia. 
O conto "Os irmãos Dagobé" faz parte da coletânea Primeiras estórias, publicada em 1962, e apresenta elementos muito marcantes na obra rosiana, como o anticlímax e a inversão da lógica da lei do mais forte. O primeiro ponto importante a ser considerado é a forma singular do livro. As vinte e uma histórias são elencadas geometricamente, num movimento cíclico em que o primeiro conto se comunica com o último, o segundo com o penúltimo e assim sucessivamente até chegar a um centro "[...] tanto físico como metafísico [...]" (FINAZZI-AGRÒ, 2009, p. 148), consistente em "O espelho", conto sem qualquer contexto espaço-temporal em que o narrador faz intensa reflexão sobre o tema da identidade. É esse centro que reflete os demais contos na formação da estrutura da coletânea.

Existe um contexto histórico, apresentado no primeiro e no último conto como "[...] o lugar onde as muitas mil pessoas faziam a grande cidade" (ROSA, 1967, p. 201). Afirma Etore Finazzi-Agrò (2009, p. 148), entre outros estudiosos, que a atenção que o autor chama para o presente da escrita remete o leitor ao momento que Guimarães Rosa e o Brasil viviam em 1962, e, portanto, a cidade em construção seria Brasília. Walnice Nogueira Galvão (2008, p. 233) aponta, porém, para a possibilidade de essa cidade ser Belo Horizonte, capital do estado natal do escritor e também planejada. Nada obsta, entretanto, que ambas as capitais se reflitam, pensando em Minas Gerais como um microcosmo do Brasil. Afinal, o que há de mais notório é o fato de, na maioria dos contos da coletânea, o autor se afastar do moderno e rápido centro urbano, preferindo o interior do país, o sertão, os pequenos arraiais que ainda existiam em Minas Gerais na época. O espaço em que se passam as histórias é eminentemente rural, lugarejos pequeninos e marginais (GALVÃO, 2008, p. 233).

Também merecem destaque as peculiaridades das personagens de Primeiras estórias. Lenira Covizzi (1978, p. 65) as nomeia como "seres de exceção", normalmente crianças, idosos, estrangeiros, portadores de "anormalidades físico-psíquicas", realizadoras de condutas que 
surpreendem o leitor e, em especial para este trabalho, aquelas que se ligam à "transgressão às regras sociais", como as personagens de "Os irmãos Dagobé", "Famigerado" e "Fatalidade", contos que apresentam sujeitos "valentes malvados que fazem justiça própria" (COVIZZI, 1978, p. 69). Essas personagens, para Walnice Nogueira Galvão (2008, p. 234), são "excêntricas", ou seja, fora da centralidade: são seres incomuns, que vivem às margens, inclusive, do desenvolvimento social e econômico que o Brasil vivia na época..

Para nosso estudo, é também importante a predominância do suspense (GALVÃO, 2008, p. 233) que envolve grande parte das narrativas. Muitas vezes o clima de tensão apresentado por meio das categorias narrativas leva o leitor a esperar desfechos que não acontecem, instaurando o anticlímax de alguns contos da coletânea. Essa característica é de fundamental importância para a análise das manifestações da justiça, conforme veremos.

\section{A justiça em "Os iirmãos Dagobé"}

Tomemos, então, os acontecimentos do conto que é objeto deste estudo. Em resumo, narra-se a história do funeral de um valentão, Damastor Dagobé, o mais velho, mais temido e o líder dos quatro irmãos que dão título à narrativa e os quais agiam com desmandos na região sertaneja onde se passam os fatos. O falecido havia sido assassinado por Liojorge, um homem visto por todos como muito honesto e que só cometera aquele ato porque o outro havia ameaçado cortar suas orelhas, não lhe restando outra saída senão agir em defesa própria.

O narrador envolve o leitor no clima tenso do funeral, em que os habitantes do arraial esperavam que, após o enterro, os outros três Dagobé, - Doricão, Dismundo e Derval - vingariam o irmão, matando Liojorge. Entretanto, algumas situações que as personagens ali presentes estranham 
são relatadas, como: a aparente serenidade - e, por vezes até, felicidade - com que os irmãos se comportavam no funeral: "Eles, os Dagobés vivos, faziam as devidas honras, serenos, e, até, sem folia mas com a alguma alegria." (ROSA, 1967, p. 27); o fato de não terem obrado vingança mais cedo e, por fim, o comportamento de Liojorge que, não obstante sua imprudente permanência no arraial após o assassinato de Damastor, ainda ousara ir ao cerimonial de sua morte e se oferecera para ajudar a levar o caixão, o que fez o povo do lugarejo desconfiar de que estivesse ficando doido.

Mais estranho, porém, foram os três irmãos aceitarem que o assassino do primogênito ajudasse na condução do caixão. Entretanto, o fato de Liojorge segurar a alça esquerda dianteira fez com o que as pessoas imaginassem que era plano dos Dagobé o matar pelas costas, o que não acontece; procede-se o enterro e, quando acaba, Doricão faz o inesperado: "Levou a mão ao cinturão? Não. A gente, era que assim previa, a falsa noção do gesto. Só disse, subitamente ouviu-se: - 'Moço, o senhor vá, se recolha. Sucede que o meu saudoso Irmão é que era um diabo de danado..." (ROSA, 1967, p. 30) e completa afirmando que iriam mudar para a cidade grande. Assim, opera-se o anticlímax, após o leitor esperar a vingança dos irmãos, que não é realizada.

O que se evidencia nesse conto de Guimarães Rosa e em outros, como o já mencionado "Corpo fechado" de Sagarana, é a presença da justiça dos valentões nas comunidades sertanejas, desafiada por um homem comum, mais fraco, mas que consegue êxito no final. Em "Os irmãos Dagobé”, a tensão perdura em toda a extensão da narrativa, a começar pela primeira frase: "Enorme desgraça" (ROSA, 1967, p. 26). A tensão permeia o relato do começo ao fim: ocorreu uma enorme desgraça, que foi o assassinato de Damastor Dagobé, e o leitor aguarda outra, que seria a vingança dos outros três irmãos contra Liojorge. Os habitantes do vilarejo não esperavam o semblante sereno dos irmãos no funeral e o comportamento de Liojorge após o assassinato do valentão, sendo sempre surpreendidos pela quebra 
de expectativa.

A justiça pelas próprias mãos é elemento temático central da história narrada: primeiramente, com a morte de Damastor que, segundo Liojorge, fora em legítima defesa, necessária para afastar um ataque do vilão; e, em seguida, pela espera da vingança dos irmãos em retribuição à morte de seu líder.

O juízo de valores que o leitor pode fazer na interpretação da narrativa é baseado na antítese da construção dos dois lados do conflito: Damastor Dagobé vs. Liojorge. O primeiro é um homem “[...] tão sordidamente avaro, ou mais, quanto mandão e cruel [...]" (ROSA, 1967, p. 27). Sua caracterização traz sempre as marcas da maldade, do egoísmo, dos desmandos e do despotismo, além de seu nome poder ser relacionado ao do temido gigante Adamastor de Camões, em Os Lusíadas, que, no Cabo das Tormentas, impedia a passagem dos portugueses que almejavam ir às Índias, da mesma forma que a presença de Damastor impedia a liberdade dos demais irmãos e, consequentemente, a paz no arraial. O narrador chega a, ironicamente, dizer que o defunto deixara um "[...] inventário de maldades" (ROSA, 1967, p. 26). Os quatro irmãos, como grupo, são apresentados como "[...] absolutamente facínoras" (ROSA, 1967, p. 26), "Demos [...]"(ROSA, 1967, p. 26), “[...] gente que não prestava" (ROSA, 1967, p. 26) e que "Viviam em estreita desunião, sem mulher em lar, sem mais parentes, sob a chefia despótica do recém-finado" (ROSA, 1967, p. 26).

Os irmãos são vistos, assim, como contrários àquilo que a população valoriza, a começar pelo modo de vida que tinham, em desunião entre si, sem família, caracterizados como demônios e facínoras. Entretanto, é a figura de Damastor que pesa no julgamento dos demais, uma vez que “[...] todos temiam mais ou menos os três vivos" (ROSA, 1967, p. 26, grifo nosso), ou seja, o temor reverencial que tinham pelos Dagobé era principalmente devido à figura do falecido, já que o medo dos demais era incerto, ou, no 
mínimo, em um grau menos intenso. Isso se evidencia na apresentação do modo como Damastor era visto em vida: “[...] o grande pior, o cabeça, ferrabrás e mestre, que botara na obrigação da ruim fama os mais moços 'os meninos', segundo seu rude dizer" (ROSA, 1967, p. 26). Toda a maldade é personificada na figura do primogênito que, além de ser o pior, ter um dizer rude e ser o chefe do grupo, é visto como o responsável por obrigar os outros três à vida de crueldade. Por isso, ficaram os três, após a morte de Damastor, "mais ou menos" temidos, porque a vida que levavam era conduzida pela vultosa maldade do irmão, ninguém podendo assegurar se, depois da "enorme desgraça" (ROSA, 1967), viriam a continuar nessa "má fama" (ROSA, 1967).

Apesar de não se ter a certeza de que os três irmãos seguiriam os passos do mais velho, a visão demoníaca dos “perversos Dagobés” (ROSA, 1967, p. 29) não é dissociada deles ao longo do funeral, principalmente de Doricão, o mais velho entre os vivos, descrito como "[...] o demônio em modo humano" (ROSA, 1967, p. 29) e contemplado como aquele que iria assumir o lugar do finado na chefia dos demais irmãos; o do meio, Dismundo, era visto como "[...] formoso homem [...]" (ROSA, 1967, p. 27) e o mais novo, Derval, o mais "social e "diligente" para com os que chegavam ao funeral. Entretanto, como aponta Ana Paula Pacheco (2006, p. 83), sabia-se da "estreita desunião" em que viviam os irmãos, juntos apenas na maldade. A morte do mais velho possibilitou que os outros fossem libertados - inclusive na questão financeira, posto que a herança deixada fora de grande valor, devido à avareza de Damastor - e pudessem seguir a vida de maneira diferente daquela a que o primogênito os obrigava.

Quanto a Liojorge, a forma como é visto pela sociedade é oposta à reputação de Damastor. $\mathrm{O}$ protagonista é apresentado pelo narrador como "[...] um lagalhé pacífico e honesto, chamado Liojorge, estimado de todos" (ROSA, 1967, p. 26). Em sua personalidade estão as características valoradas como boas - a honestidade e a pacificidade -, sendo descrito, 
ao contrário do outro, como alguém que convivia em harmonia com a sociedade, posto que por de todos era estimado. Parece ser esse o traço que mais aguça a diferença entre os dois: um, temido pela sociedade, incapaz de se socializar e de viver pacificamente; o outro, pelo contrário, ostentava os valores mais prestigiados pelas pessoas do lugar e tinha a estima de todos.

Talvez por isso mesmo, pela pacificidade e honestidade que compunham a fama de Liojorge, Damastor não pestanejou ao ameaçar cortar-lhe as orelhas, por não ter tido a malícia de imaginar que sujeito como ele poderia revidar com o tiro que acabou ceifando sua vida. Entretanto, o conflito que culminou na morte do mais velho Dagobé é narrado profusamente no conto e sem as necessárias informações que permitiriam analisar a razão de cada um no acontecimento. Sabe-se que a agressão partiu de Damastor, o qual "[...] sem sabida razão, ameaçara de cortar-lhe as orelhas" (ROSA, 1967, p. 26, grifo nosso). Logo, é justamente a forma pela qual cada um dos litigantes é visto pelo narrador - que tem sua voz misturada à das personagens presentes no velório - que induz o juízo sobre qual deles estava com a razão. Isso conduz o leitor a imaginar que ou o valentão, por ser cruel, rude e despótico, investiu contra o pacato Liojorge sem motivo algum, pelo mero deleite de fazer uma maldade, ou o fez por alguma razão irrelevante.

Já a expectativa de essa razão ter sido provocada por Liojorge parece ficar fora de possibilidade por parte do leitor, justamente pela inversa opinião pública de cada um, pois o lagalhé é reputado como honesto e pacífico. Todavia, não pode ser completamente refutada, pois é de se estranhar o fato de um homem tão pacífico ter em porte uma garrucha, o que pode ser explicado pelo fato de, no lugar, não haver autoridade (ROSA, 1967, p. 28), porém, é possível que ele já estivesse esperando a agressão que acabou sofrendo.

Além disso, é destacado também o sentimento - talvez por culpa ou por medo - de resignação que assolou o rapaz após a morte do Dagobé: 
“[...] aquele pobre Liojorge permanecia ainda no arraial, solitário em casa, resignado já ao péssimo, sem ânimo de nenhum movimento." (ROSA, 1967, p. 27). Seja como for, a própria escolha dos adjetivos atribuídos para as duas partes do conflito já demonstra que o assassino de Damastor foi absolvido pela comunidade local.

Inclusive, durante o funeral, as pessoas só falavam a respeito “[...] do rapaz Liojorge, criminal de legítima defesa, por mão de quem o Dagobé Damastor fizera passagem daqui” (ROSA, 1967, p. 28, grifo nosso). Chama a atenção o uso da expressão "'legítima defesa", um instituto jurídico que, segundo Luiz Regis Prado (2014, p. 330), é a “[...] mais saliente e antiga causa de justificação, que transforma uma ação típica em lícita, amparada pela ordem jurídica”. Segundo o artigo 25 do Código Penal, considerase em legítima defesa quem "[...] usando moderadamente dos meios necessários, repele injusta agressão, atual ou iminente, a direito seu ou de outrem.” (BRASIL, 1940).

Nesse sentido, ensina o penalista Júlio Mirabete (2012, p. 168) que quatro são os requisitos que a ação de uma pessoa deve apresentar para a configuração da legítima defesa: a) reação a agressão atual ou iminente e injusta; b) defesa de um direito próprio ou alheio; c) moderação no emprego dos meios necessários à repulsa e d) elemento subjetivo, ou seja, o conhecimento de que está sendo agredido.

A análise desse instituto se faz necessária porque Liojorge defende-se apresentando exatamente os requisitos anteriores a seu favor: "Que o rapaz Liojorge, ousado lavrador, afiançava que não tinha querido matar irmão de cidadão cristão nenhum, puxara só o gatilho no derradeiro instante, por dever de se livrar, por destinos de desastre" (ROSA, 1967, p. 28, grifos nossos). Vários são os destaques dos trechos mencionados, a começar pela forma como são relatados, muito semelhantes a um relatório judicial de defesa.

Importe é que a defesa apresentada indiretamente no discurso por 
Liojorge parece mesmo cumprir cada um dos requisitos apontados: sua atitude foi uma reação à investida de Damastor, que era atual, em defesa da própria integridade física (direito próprio) e mostrava-se necessária para afastar a agressão, uma vez que ele só puxou o gatilho no último instante, ao perceber que não haveria outra forma de repulsa ao agressor.

Porém, pode restar uma dúvida: Damastor atacou Liojorge com um punhal (ROSA, 1967, p. 26) e este o repeliu com um tiro de garrucha. Esse meio de defesa foi moderado? Segundo a essência da legítima defesa, sim: “[...] 'meio necessário' é aquele que o agente dispõe no momento em que rechaça a agressão, podendo ser até mesmo desproporcional com o utilizado no ataque, desde que seja o único à sua disposição no momento" (MIRABETE; FABBRINI, 2012, p. 171).

Logo, ao se defender, Liojorge é enquadrado perfeitamente na legítima defesa, o que garante a legalidade de seu ato no juízo do justo ou injusto naquele episódio. Ademais, o personagem ainda se apresenta desarmado perante os três irmãos vivos, para comprovar mais veementemente que tivera razão no ocorrido: "Que matara com respeito. E que, por coragem de prova, estava disposto a se apresentar, desarmado, ali perante, dar a fé de vir, pessoalmente, para declarar sua forte falta de culpa, caso tivesse lealdade" (ROSA, 1967, p. 28, grifo nosso). A apresentação pública de Liojorge provocou o estarrecimento de toda a gente, e pode ter sido fundamental para a decisão dos Dagobé de não vingarem o irmão, principalmente pela reiterada posição de respeito que aquele apresentou em face do falecido. Afinal, os três irmãos, também por respeito, cuidaram primeiro do funeral de Damastor para, só depois, conversarem com Liojorge sobre o ocorrido.

Sobre isso, a opinião pública do arraial - que conhecemos pela voz do narrador - parece acompanhar tal costume. Há a consciência de que a lei do sertão obedece ao princípio de talião, e, portanto, sangue se paga com sangue. Atribui-se, porém, a cada um o direito natural de ter o cerimonial de seu falecimento, como se percebe no trecho: "Sangue por sangue; mas, por 
uma noite, umas horas, enquanto honravam o falecido, podiam suspender as armas, no falso fiar. Depois do cemitério, sim, pegavam o Liojorge, com ele terminavam" (ROSA, 1967, p. 27). É esse respeito ao morto que se impõe como uma lei universal, que está acima da lei dos homens e que é absorvida pela opinião da comunidade em que o narrador se insere.

O narrador, como voz da população do arraial em que a história se passa, é o grande responsável pela tensão que perdura em todo o conto na expectativa da vingança que seria realizada pelos Dagobé, "Sendo o que se comentava, aos cantos [...]" (ROSA, 1967, p. 27). A justiça realizada pelas próprias mãos parece ser uma realidade assimilada e aceita pela sociedade local, até porque "[...] no lugar, ali nem havia autoridade (ROSA, 1967, p. 28), ou seja, temos o espaço sertanejo em que o Estado não está presente para assegurar a justiça. Aliás, não só o governo está ausente, mas, como se vê, a palavra autoridade remete a qualquer outra instituição que possa, de alguma forma, apresentar-se hierarquicamente acima do povo, o que contribui para a consolidação despótica dos valentões que, no conto em pauta, são os irmãos Dagobé. Nem mesmo uma autoridade religiosa poderia ser rogada no lugar: "Não ia passar na igreja? Não, no lugar não havia padre" (ROSA, 1967, p. 30).

Por conhecerem a fama dos irmãos e a lei do sangue por sangue, $o$ narrador e as demais personagens interpretam a maioria das atitudes dos valentões como preparativos para a vingança, e, por vezes, parece que esse é o desejo dos moradores do arraial, como, por exemplo, na passagem “[...] os chefes de tudo, não iam deixar uma paga em paz: se via que estavam de tenção feita. Por isso mesmo, era que não conseguiam disfarçar o certo solerte contentamento, perto de rir. Saboreavam já o sangrar" (ROSA, 1967, p. 27). Ora, conhecendo o final da história, pode-se afirmar que o "certo contentamento" incontido no semblante dos Dagobé devia-se ao possível sentimento de libertação que tiveram após a morte do irmão, que os tinha posto na "má fama", tratando-os como "meninos". Com 
o falecimento do líder, poderiam traçar os próprios rumos, indo para a cidade grande e deixando aquela vida para trás. Porém, a comunidade ali presente supõe, imagina, cria outras situações de acordo com a reputação das personagens centrais e do desencadeamento que presume lógico para os acontecimentos.

Por isso, também foi imputada a Liojorge a insanidade pela escolha que fizera de não ter ido embora dali: "O Liojorge, sozinho em sua morada, sem companheiros, de doidava? Decerto, não tinha a experiência de se aproveitar para escapar, o que não adiantava - fosse aonde fosse, cedo os três o agarravam. Inútil resistir, inútil fugir, inútil tudo" (ROSA, 1967, p. 28). Tanto é certo para o narrador, pela fama dos Dagobé, que eles não perdoariam o assassinato de um irmão, buscando vingança onde quer que fosse, como também a perda de juízo do assassino do líder ao não fugir.

A presença dessa "gente", habitantes de lugares de margem do Brasil, que cria, supõe e imagina acontecimentos não é rara em Primeiras estórias, como, por exemplo, em "A terceira margem do rio": "A estranheza dessa verdade deu para estarrecer de todo a gente. Aquilo que não havia, acontecia" (ROSA, 1967, p. 33, grifo nosso). Ademais, "Os irmãos Dagobé” tem forte relação com "A benfazeja”: assim como a Mula-Marmela, Liojorge, apesar de cometer um assassinato, faz um bem para a comunidade em que vive, libertando-a de um homem sem escrúpulos, visto como um demônio, que, despoticamente, dominava o lugar. Além disso, sua atitude também foi vista como uma libertação para os outros três Dagobé, e, da mesma forma como no conto em questão, em "A benfazeja”, a opinião pública tem evidência na narrativa, mas, por seu turno, não se confunde com a visão do narrador, que a desafia - "Pensem, meditem nela, entanto" (ROSA, 1967, p. 134) -, julga-a - "A gente não revê os que não valem a pena” (ROSA, 1967, p. 125) -, uma vez que as pessoas do lugar enxergavam a protagonista de modo preconceituoso, e o narrador tenta provar que o bem que a mulher fizera ao lugar superava qualquer prejulgamento. 
Em “Os irmãos Dagobé”, o leitor é conduzido pelas opiniões do narrador, que vão construindo a tensão da espera cada vez mais forte no conto. Conforme o enterro vai chegando ao final, a confirmação da vingança de mão própria vai ficando mais evidente: "Os três Dagobés, armados. Capazes de qualquer supetão, já estavam de mira firmada. Sem se ver, se adivinhava" (ROSA, 1967, p. 30). Esse trecho evidencia ainda mais que a tensão criada é fruto da imaginação do narrador, juntamente com as pessoas que participam do funeral, e os comentários continuam: “[...] baixado o caixão na cova, à queima-bucha o matavam; no expirar de um credo" (ROSA, 1967, p. 30). Tais comentários e imaginações acentuam a importância da justiça privada vingativa, que é esperada pelo leitor também, e isso vai dilatando o tempo do discurso na construção da tensão da história. Quanto mais se aguarda a atitude dos Dagobé contra Liojorge, mais se vai tendo a impressão de que o funeral demora muito para acabar: “Tinha caído outra chuva. O prazo de um velório, às vezes, parece muito dilatado" (ROSA, 1967, p. 29).

Outro elemento importante é a presença da chuva, que acompanha o conto do seu início - "Lá fora, a noite fechada; tinha chovido um pouco" (ROSA, 1967, p. 26), passando pelo momento do enterro - "E, nisso, caía uma chuvinha"(ROSA, 1967, p. 30) -, até o seu final - "E outra chuva começava"(ROSA, 1967, p. 30). A chuva constante contribui para aumentar o clima fechado e tenso da história, além de poder ser interpretada como uma água de renovação, que estava lavando aquele lugar, que teria um recomeço, após a partida dos três valentões e da morte do chefe deles, que tanto mal infringiam para os moradores daquele espaço. Além disso, a chuva não simboliza tão somente a libertação de quem ali morava, como também a dos próprios irmãos que se mudariam para cidade grande, encontrando outro rumo para sua vida.

É no clima tenso, elaborado pelo narrador, que ocorre o anticlímax: a espera do leitor para ver o desdobrar de uma vingança - portanto, 
tentativa de justiça pelas próprias mãos - é frustrada pela surpreendente atitude dos rudes Dagobé que, absolvendo Liojorge, aceitam a culpa do irmão. $\mathrm{O}$ anticlímax pode ser visto também como conduzido pela ação providencial, uma vez que se arranja a desarmonia presente naquele espaço, consubstanciada na figura de Damastor Dagobé, partindo-se da aceitação que os demais irmãos tiveram da culpa deste e da não culpa do outro. Segundo Ana Paula Pacheco (2006, p. 82, grifos da autora): “[...] os irmãos concordam, numa lógica de justiça a que a família parece jamais ter aderido, ter sido necessário o ato de Liojorge; o Irmão, maiúsculo, endiabrado, fizera por merecer...”.

A providência, justiça divina na obra rosiana, deixa sinais de sua atuação ao longo da narrativa. Em "Os irmãos Dagobé”, podemos ver na chuva que lava o lugarejo um de seus símbolos e, além disso, a frase constante no cemitério em que Damastor é enterrado: "Aqui, todos vêm dormir" (ROSA, 1967, p. 30). Sabe-se que escritos como esse são muito comuns em cemitérios, principalmente em cidades do interior, em que a presença do cristianismo é ainda muito marcante. Porém, tal enunciado não é colocado à toa no conto; sua mensagem se baseia no nivelamento de todos perante a morte, podendo ser visto, assim, como mais um sinal de que a justiça divina será realizada no final da narrativa. É assim que “[...] a graça toma o lugar da desgraça [...]" (PACHECO, 2006, p. 85).

Ademais, valores tidos como intrínsecos ao homem - pode-se dizer: leis divinas, ou universais - apresentam-se de maneira superior às convenções do sertão narrado; o respeito que tanto os irmãos quanto Liojorge dispensam ao morto são fundamentais na determinação dos acontecimentos finais da história. O cerimonial que honrava a morte de Damastor foi, afinal, visto como uma trégua às armas. 
Portanto, encontra-se, no conto em tela, a efetiva presença de duas manifestações da justiça. Começa-se com um caso de justiça de mão própria, que aparenta ser legítima. É mais uma situação de inversão da lei do mais forte, pois, aquele que era afamado como tal, rude, demoníaco e acostumado com a violência, sucumbe perante um joão-ninguém, pacato e honesto. A partir disso, espera-se pela vingança dos irmãos, "gente que não prestava" que, ao que tudo indicava, deveriam derramar o sangue de Liojorge pelo sangue derramado do primogênito. Toda a expectativa, porém, é quebrada; a providência divina organiza os acontecimentos, invisivelmente, mas deixando alguns sinais, como a chuva que libertava tanto o espaço quanto os Dagobé do despotismo violento do finado. Num espaço sertanejo de margem em que o Estado não se faz presente, a justiça fica a cargo das próprias personagens e, indiretamente, da mão divina.

\section{Referências}

BRASIL. Código Penal. Diário Oficial da União, Rio de Janeiro, p. 2391, 31 dez. 1940.

CAMÕES, Luís Vaz de. Os Lusíadas. Introdução e notas de Alexei Bueno. 2a edição. Rio de Janeiro: Nova Fronteira, 2018.

CANDIDO, Antonio. O homem dos avessos. In: CANDIDO, Antonio. Tese e antítese. Rio de Janeiro: Ouro sobre Azul, 2006, p. 111-130.

CASTRO, Flávia Lages de. História do direito: geral e Brasil. Rio de Janeiro: Lumen Juris, 2011.

COVIZZI, Lenira. O insólito em Guimarães Rosa e Borges. São Paulo: Ática, 1978.

FAUSTO, Boris. História concisa do Brasil. São Paulo: Edusp, 2014. 
FINAZZI-AGRÒ, Ettore. A memória bêbada: trauma e representação nas Primeiras estórias. In: CHIAPINI, Ligia; VEJMELKA, Marcel. (Org.). Espaços e caminhos de João Guimarães Rosa: dimensões regionais e universalidade. Rio de Janeiro: Nova Fronteira, 2009.

GALVÃO, Walnice Nogueira. Mínima mímica. São Paulo: Companhia das Letras, 2008.

GENETTE, Gérard de. Discurso da narrativa. Tradução de Fernando Cabral Martins. Lisboa: Vega, [197-].

LÉVY-BRUHL, Lucien. Sociologia do direito. Tradução: Antonio de Pádua Danesi. São Paulo: Martins Fontes, 2010.

MIRABETE, Júlio Fabrini; FABRINI, Renato. Manual de direito penal. São Paulo: Atlas, 2012.

NADER, Paulo. Filosofia do direito. Rio de Janeiro: Forense, 2014.

NUNES, Benedito. De Sagarana a Grande sertão: veredas. In: NUNES, Benedito. Crivo de papel. 2. ed. São Paulo: Ática, 1996. p. 247-262.

PACHECO, Ana Paula. Lugar do mito: narrativa e processo social nas Primeiras estórias de Guimarães Rosa. São Paulo: Nankin, 2006.

PRADO, Luiz Régis. Curso de direito penal brasileiro, São Paulo: RT, 2014.

RIBEIRO, Gustavo de Mello Sá Carvalho. A “mão pronta” e a divina: manifestações da justiça em contos rosianos. $134 \mathrm{f}$. Dissertação (Mestrado em Estudos Literários). Faculdade de Ciências e Letras, Universidade Estadual Paulista. Araraquara, 2016.

ROSA, João Guimarães. Sagarana. Rio de Janeiro: José Olympio, 1965. 
ROSA, João Guimarães. Primeiras estórias. Rio de Janeiro: José Olympio, 1967.

ROSA, João Guimarães. Grande sertão: veredas. Rio de Janeiro: Nova Fronteira, 2006.

SANTOS, Boaventura de Sousa. A justiça popular em Cabo Verde.
São Paulo: Cortez, 2005.

Self-defense, private revenge, providence: the faces of justice in "os irmãos dagobé” by Guimarães Rosa

Abstract: One of the main themes present in Guimarães Rosa's work, the theme of justice, was elaborated in a very peculiar way and remains current today. In the sertanejo space of most of the stories he wrote, there is no presence of the State and the justice is performed by the characters themselves or by divine providence. The core of this work is to verify the construction of such a theme in the short story "Os Irmãos Dagobé" from Primeiras estórias, published in 1962. It is also interesting to find out if the treatment of this matter is consistent with the socio-historical environment represented in the composition. To do so, we started from the analysis of narrative elements, such as the story, the narrator, the characters and the social space, based on Genette's postulates in $O$ discurso da narrativa, to observe how these categories build the subject in question. Finally, it is concluded that the absence of the State in the rural space of Minas Gerais, where the story takes place, leads the characters to do justice by their own hands in search of revenge in self-defense and that, in this path, we have a providential action that takes peace to the space represented through the inversion of the law of the strongest. The theoretical basis of the work, in addition to the structuralist work already mentioned, consists of the criticism of our corpus, for example, O lugar do mito by Ana Paula Pacheco. In addition, we used philosophical and legal theories of justice, such as Filosofia do direito, by Paulo Nader.

Keywords: Brazilian literature. Guimarães Rosa. Justice.

Recebido em: 25/12/2020

Aceito em: 08/09/2021 
Varia 


\section{Traduzir-da-tradução: do Urucuia ao Reno, do Reno ao Urucuia}

\section{Jander de Melo Marques Araújo ${ }^{1}$}

Resumo: $\mathrm{O}$ artigo analisa a correspondência entre João Guimarães Rosa e seu primeiro tradutor alemão, Curt Meyer-Clason, destacando trechos que exponham a concepção de tradução e linguagem dos dois missivistas. Ao longo da análise, o texto dialoga com reflexões sobre tradução de Walter Benjamin, Haroldo de Campos e Antoine Berman. Por fim, há um breve comentário sobre algumas soluções de Meyer-Clason, em alemão, para a ficção de Rosa, desde exemplos lexicais até um trecho já em forma de parágrafo. Palavras-chave: Carta. Tradução. Alemão. Guimarães Rosa. Curt Meyer-Clason.

Viajar! - mas de outras maneiras: transportar o sim desses horizontes!...

Guimarães Rosa

[...] quase sempre as dúvidas decorrem do "vício" sintático, da servidão à sintaxe vulgar e rígida, doença de que todos sofremos. Duas coisas convém ter sempre presente: tudo vai para poesia, o lugar-comum deve ser proibida a entrada, estamos é descobrindo novos territórios do sentir, do pensar, e da expressividade; as palavras valem "sozinhas". Cada uma por si, com sua carga própria, independentes, e às combinações delas permitem-se todas as variantes

e variedades.

Guimarães Rosa

sermo riobaldinus traductus est. Curt Meyer-Clason

1 Doutorando em Estudos de Literatura (Literatura Comparada) na Universidade Federal Fluminense (UFF). Mestre em Ciência da Literatura (Teoria Literária) pela Universidade Federal do Rio de Janeiro (UFRJ). Licenciado em Letras (Português/Literaturas) pela UFF. Bacharel em Produção Cultural pela UFF. 
s cartas impressas ainda guardam características muito próprias e originais, principalmente quando confrontadas com uma contemporaneidade hiperconectada e líquida, que se dessensibilizou física e mentalmente do manuscrito e do datiloscrito, desvalorizando-os até mesmo no campo da preservação e da memória. Apesar disso, diante do que o tempo e o trabalho dos pesquisadores preservaram nesses suportes tradicionais, uma característica valorizada nessas cartas mais antigas, embora nem tão antigas assim, é aquela relacionada à sua natureza privada, que tem como resultado, em termos de conteúdo, a presença da liberdade e da sinceridade instintivas que os escritores se oferecem na exposição de seus pensamentos. Assim, ao pensarmos em uma carta, não a imaginamos sendo divulgada. Ela nasce no ambiente privado, é envelopada, lacrada e lida de forma confidencial. Lembremos, como ênfase a tal aspecto, os meios pelos quais as cartas já foram enviadas. São os casos dos pomboscorreio e dos pneumáticos, por exemplo. O pombo-correio, pelos céus, é mais particular ainda. Do remetente ao destinatário, apenas uma ave é testemunha. O pneumático, modo de envio antigo por meio de tubos com pressão a ar, enviava a carta pelos subterrâneos de uma cidade. Mais uma vez, temos aqui o destino privado e confidencial das cartas. Sobre o céu ou sob a terra, boa parte delas é escrita para ser lida apenas por dois missivistas.

Ao lado disso, podemos citar a importância que as cartas possuem para os estudos literários. Cartas - e também se incluem aqui os diários - são um suporte para a escrita bastante instigante e revelador da arte literária, inclusive são gêneros, como sabemos, que são utilizados pelos próprios escritores na composição de suas narrativas ficcionais. Entretanto, o que se ressaltará neste texto, por meio de uma análise detida de alguns fragmentos, é que, através das cartas, ficamos sabendo não só da vida privada dos autores mas também dos mecanismos e contextos de escrita das várias obras de um escritor. Se, por um lado, quem escreve uma carta 
nem sempre quer torná-la pública, a ponto de queimá-la, por outro, há a importância desses documentos, muitas vezes com qualidade literária, para os que pesquisam literatura.

Como se sabe, um dos ramos dos estudos literários é a tradução e seu estudo, a tradutologia. Ela desdobra a obra em outra língua e, num estudo atento, acaba revelando camadas profundas da escrita do texto original. No entanto, boa parte das vezes, os leitores e o próprio escritor da obra original não conseguem ter contato com o texto traduzido. No caso do autor, seja porque já tenha falecido no momento da tradução, seja porque não tenham chegado às suas mãos as traduções, ou até mesmo devido ao desconhecimento do escritor da língua-alvo da tradução. $\mathrm{Da}$ parte do leitor, há, além da impossibilidade material de ter contato com a obra traduzida, o desconhecimento da importância do texto traduzido para melhor compreender, por meio de um ângulo distinto, a obra original.

A publicação da correspondência de João Guimarães Rosa (19081967) com seu tradutor alemão Curt Meyer-Clason (1910-2012) abriu uma importante perspectiva para a discussão dos estudos de tradução. Sua importância está não apenas em uma discussão sobre tradução que foi proporcionada a Guimarães Rosa em vida mas também na figura sensível de seu tradutor, com seu conhecimento e sua paixão pela literatura e cultura brasileiras.

Entre janeiro de 1958 e agosto de 1967 - portanto, num período de quase dez anos -, João Guimarães Rosa e Curt Meyer-Clason se corresponderam por meio de oitenta cartas. Nelas, discute-se a tradução das principais obras de Rosa para o alemão, sobretudo Grande sertão: veredas. Também temos, nessa correspondência, discussões sobre a editora que publicará os livros de Rosa na Alemanha e comentários sobre as traduções que estão sendo realizadas para outras línguas, como o inglês (Harriet de Onís), francês (Jean-Jacques Villard) e italiano (Edoardo Bizzarri), tendo em vista que Rosa se correspondia, ao mesmo tempo, com os outros 
tradutores. Esse fluxo de contatos acontece, de fato, porque, no final década de 1950, e, sobretudo, na de 1960, o escritor brasileiro começa a discutir os direitos para a publicação de seus escritos no exterior, já que passa a receber muitos convites para a sua obra ser traduzida. Encontramos, nas cartas, muitas notas e pequenos comentários, por parte dos dois missivistas, sobre dúvidas de termos, dos neologismos e da sintaxe da obra de Guimarães Rosa. As cartas são um imenso mural tira-dúvidas e reflexivo, que, para o leitor de hoje, é um deleite, pois revela paralelamente os mecanismos de escrita e o projeto literário do escritor brasileiro, bem como a poética tradutória de seu correspondente alemão. Em suma, são cartas cujo conteúdo mostra que a tradução se processa como "uma experiência que pode se abrir e se (re)encontrar na reflexão" (BERMAN, 2007, p. 18).

Para entendermos um pouco o que significa o encontro desses dois escritores pelas cartas - visto que se encontraram pessoalmente pouquíssimas vezes -, temos que comentar um pouco tanto sobre Guimarães quanto, e principalmente, sobre Curt Meyer-Clason.

Sobre Guimarães Rosa, devemos, primeiramente, apontar a natureza poliglota de sua obra. Essa natureza torna o deslocamento português-alemão-português mais complexo e, ao mesmo tempo, mais rico para os estudos de tradução, para não dizer que estamos lidando com uma língua neolatina e outra germânica, ou seja, com uma tradução entre línguas de famílias linguísticas distintas. Por outro lado, a própria obra de Rosa se constitui no limiar da língua portuguesa, tornando a tarefa do tradutor mais desafiadora. Ele utilizou termos arcaicos da língua, além de ter criado milhares de palavras, como bem desvelou O léxico de Guimarães Rosa, de Nilce Sant'Anna Martins (2021). Como se sabe, muitas palavras não foram criadas apenas com base no português. Seus textos apresentam um léxico também devedor às diversas línguas estrangeiras que Rosa conhecia, inclusive o alemão. Há um trecho em que o próprio escritor fala sobre o seu conhecimento de línguas e que ilustra bem o terreno pró- 
babélico sobre o qual estamos pisando:

Falo: português, alemão, francês, inglês, espanhol, italiano, esperanto, um pouco de russo; leio: sueco, holandês, latim e grego (mas com o dicionário agarrado); entendo alguns dialetos alemães; estudei a gramática: do húngaro, do árabe, do sânscrito, do lituânio, do polonês, do tupi, do hebraico, do japonês, do tcheco, do finlandês, do dinamarquês; bisbilhotei um pouco a respeito de outras. Mas tudo mal. E acho que estudar o espírito e o mecanismo de outras línguas ajuda muito à compreensão mais profunda do idioma nacional. (ROSA apud MEIGUINS, 2006, p. 44).

A língua alemã é a segunda citada nesse trecho e, além disso, mais adiante, ele menciona o seu conhecimento de alguns dialetos alemães. Lembro também, a fim de mostrar sua relação com o alemão e a cultura alemã, que Rosa era diplomata e, durante alguns anos, a partir de 1938, estabeleceu-se como cônsul-adjunto em Hamburgo, Alemanha. Aliás, há um diário do escritor brasileiro desse período, porém ainda não divulgado inteiramente.

Sobre Curt Meyer-Clason, pode-se dizer que, nascido em 1910, não se envolveu inicialmente com a tradução e a literatura brasileira. Trabalhou primeiro com o comércio de importação de algodão, o que proporcionou sua vinda para a América Latina, especificamente para o Brasil e a Argentina. Na verdade, Clason tem uma relação mais complexa com o Brasil, na época da ditadura Vargas, com acusações de espionagem, confissão sob tortura, condenação a um longo tempo de prisão - onde pôde conhecer e ler a nossa literatura - e um período em que trabalhou com comércio exterior no Rio de Janeiro (ESTEVES, 2012). Assim, depois de morar por aqui de 1937 a 1954, nessa longa e complexa experiência, Clason volta à Alemanha e começa a trabalhar como Lektor (leitor-revisor) e como tradutor e escritor. É impressionante essa trajetória tardia no mundo editorial se listarmos 
aqui os autores que ele já traduziu, tais como: Machado de Assis, Mário de Andrade, Jorge Amado, Carlos Drummond de Andrade, João Cabral de Melo Neto, Ferreira Gullar, João Ubaldo Ribeiro, Nélida Piñon, Ignácio de Loyola Brandão, Clarice Lispector, Fernando Sabino, Oswald de Andrade, Cecília Meireles, além dos poetas concretistas e de outros autores latinoamericanos (Jorge Luis Borges, Pablo Neruda, Gabriel García Márquez etc.) - muitos com os quais ele também se correspondeu. Segundo o jornalista Bernardo Esteves (2012), a Amazon alemã oferece pouco mais de 100 livros traduzidos por Clason.

Voltando às influências do pensamento alemão na obra de Guimarães Rosa, destaco o fato de Grande sertão: veredas ser um caudaloso monólogo do personagem Riobaldo Tatarana. É um livro com uma referência implícita ao mito fáustico, principalmente àquele desenvolvido por Goethe em seu Fausto. Não é à toa que Rosa diz que a "a tradução e publicação em alemão me entusiasma, por sua alta significação cultural, e porque julgo esse idioma o mais apto a captar e refletir todas as nuances da língua e do pensamento em que tentei vazar os meus livros" (ROSA; MEYER-CLASON, 2003, p. 70). Em outra carta, escreve também: “De todas, será a alemã a versão mais bem realizada, a melhor - tenho a certeza. Nada vale mais, em assuntos assim, que o parentesco anímico, as afinidades de espírito" (ROSA; MEYER-CLASON, 2003, p. 125). A tradução para o alemão é de tal importância para o escritor brasileiro que ele ainda retoma o tema no seguinte trecho:

[...] sempre achei que seriam [os meus livros], principalmente, leitura para alemães - gente que sente de modo agarrado e afetivo a natureza, e que precisa, a todo momento, de maneira inadiável, de apoiar-se na metafísica. Mesmo, em horas mais devaneadas, chegava a pensar que aqueles livros, tão brasileiros, e mineiros, estariam contudo ainda algum tanto virgens, irrevelados, enquanto não recebessem a sanção e bênção dos leitores alemães, os de fato 
mais capazes de "ver tudo" neles. (ROSA; MEYERCLASON, 2003, p. 324-325).

Por outro lado, penso que, nesses comentários, há uma idealização do idioma, da cultura e do leitor alemão por parte de Rosa - além de uma mentalidade eurocêntrica -, já que, do ponto de vista da ciência da linguagem e da linguística, para não dizer de uma antropologia linguística, qualquer idioma seria capaz de traduzir sua prosa, e, por parte da estética da recepção, um leitor atento - um vaqueiro estudioso e leitor, por exemplo - também apreenderia a nuances das narrativas rosianas. Por sua vez, lembremos que Rosa surgiu em português brasileiro, e não em alemão; portanto, foi a língua brasileira que foi capaz de plasmar suas experimentações linguísticas e sua cosmologia ficcional. Para o tradutor, não resta dúvida de que, para traduzir o escritor mineiro para outra língua, é preciso, sim, que se faça o abrasileiramento da língua alemã - próximo ao sentido exposto por Walter Benjamin, por meio de uma citação, em seu ensaio seminal (BENJAMIN, 2011, p. 117-118) - ou de qualquer outra língua, pois é daí que a tradução atingirá a sua potência rosiana. Em contrapartida, seria importante lembrar, por exemplo, que Rosa se esqueceu da língua húngara tão elogiada pelo escritor no prefácio de uma edição de contos reunidos por Paulo Rónai, e que, além disso, talvez seu idioma narrativo encontrasse caminhos notáveis em um idioma não ocidental, como chinês ou japonês. E o tupi e o iorubá? Como se vê, há muitas veredas tradutórias possíveis.

Como já escrevi, o Grande sertão é o Fausto brasileiro - no sentido do mito universal fáustico. Por sua importância frente à mentalidade alemã, poderíamos pensar que esse seria o principal motivo pelo qual, da obra de Guimarães Rosa, este tenha sido o seu primeiro livro a ser publicado na Alemanha. No entanto, o motivo foi uma questão de gosto por parte do leitor alemão. Isso é interessante, porque uma das maneiras de entrar na obra de Rosa é pelos seus contos, o que também poderia ser um porto 
seguro para o tradutor. Entretanto, Curt Meyer, conhecedor do mercado editorial alemão, diz que o leitor alemão prefere ler um grande romance de dado autor para depois se aventurar nos contos. O fato é que o Grande sertão é o livro mais discutido nas cartas e teve várias edições esgotadas assim que foi publicado. A propósito, mesmo não sabendo do resultado das escolhas editoriais feitas, Rosa confiou em Curt Meyer-Clason e seguiu as indicações de seu tradutor desde o começo, da editora que publicaria as suas obras até a maneira de divulgá-las na Alemanha.

O que observamos na sequência das cartas é o nascimento de uma grande confiança entre Rosa e Clason. A mudança de tratamento ao longo das cartas ilustra isso. Eles ficam mais íntimos e constantemente passam a saudar os familiares um do outro. Assim, seguindo as cartas de Clason, temos, por exemplo: Excelentíssimo Senhor Ministro; Prezado Senhor; Prezado Amigo e Senhor; Mui Prezado Amigo e Senhor; Caro Senhor; Caro Mestre.

Dessa confiança e maneira fraterna com as quais se relacionam mutuamente, aliadas ao conhecimento da língua alemã de Guimarães Rosa, nasce as traduções das obras desse autor. Podemos dizer, assim, que há uma coautoria no processo das traduções. Clason sempre a perguntar. Rosa sempre pronto a responder e alimentar o seu tradutor com textos críticos, a fim de que a tradução também seja um movimento reflexivo. $\mathrm{O}$ que se observa, na leitura dessas cartas, não é um autor que pede fidelidade ao original. Os pedidos são por parceria e recriação constantes. Clason foi um tradutor que compreendeu não só a natureza sui generis dos livros de Guimarães Rosa mas que também desenvolveu a sua tarefa tradutória como forma também sui generis de fazer literatura - poesia acima de tudo, diz ele em certo momento, a afirmar que também é autor, embora conhecedor profundo da natureza transitória da tradução. Sobre este último ponto, Clason nos diz: 
[...] não posso me comprometer a fazer mais porque sou um iniciado, um iniciado maldito, danado e desgraçado, um maldito iniciado na utopia do ato de traduzir que continuará sendo uma utopia e uma impostura até o dia do Juízo Final. [...] Se o Senhor sonha com setecentos anos, posso apenas esperar que o Sertão alemão resista talvez $5 \%$ deste espaço de tempo, ou seja, 35 anos. Este é um fato amargo: toda tradução tem um tempo de vida restrito. Não há imortalidade para traduções. (ROSA; MEYERCLASON, 2003, p. 271-272).

Essas cartas apresentam discussões acerca de traduções e também crítica. Crítica entendida como a abertura da obra original para novos movimentos e novas leituras. Bem sabemos que a tradução já é crítica. Porém, temos a crítica desenvolvida pela leitura profunda da obra, que não necessariamente se foca na tradução stricto sensu. Nesse sentido, separei dois momentos em que há críticas para além da tradução, ou melhor, um sair da tradução por um instante, a fim de melhor voltar a ela, visto que o movimento tradutório de Clason é, do mesmo modo, tentativa de entendimento, de simples frases e palavras até o significado desse narrador caudaloso chamado Riobaldo. Temos, então, Clason refletindo sobre a obra de Rosa, em uma carta de 21 de agosto de 1967:

É correto afirmar que em Rosa vem primeiro o ser humano e depois a linguagem? Ele não procura a realidade na própria linguagem, ele procura com ela perscrutar através da linguagem a realidade humana. Para Rosa, a linguagem não é um substituto do homem, mas o meio de torná-lo visível, pensável, perceptível e palpável. Poderíamos dizer: em Rosa, o homem e a linguagem são um. Ou expressando de outro modo: a linguagem não retorna para si mesma de mãos vazias. Ela é o veículo, o portador, a expressão, o instrumento. Ou: a sua escrita, a sua ambição de fazer arte não precede nenhuma estética 
que é justificada por ela. (ROSA; MEYER-CLASON, 2003, p. 410).

Ao que Rosa responde, na carta de 27 de agosto de 1967, concordando com Clason, explicando sua noção de língua e demonstrando, assim, afinidades eletivas com o seu tradutor:

Sobre a THESE que expõe: Esplêndidas palavras! Tudo certo, exato, e finalmente expressado, fiel ao que é ou que pelo menos quer ser o meu ponto-desentir, conforme luto por realizá-lo em meus livros e escritos. [...]

[...] A língua, para mim, é instrumento: fino, hábil, agudo, abarcável, penetrável, sempre perfectível, etc. Mas sempre a serviço do homem e de Deus, do homem de Deus, da Transcendência. (ROSA; MEYER-CLASON, 2003, p. 412).

Por sua vez, Guimarães Rosa também fala sobre a sua obra, envolvendo o seu ethos como escritor àquele de seu tradutor:

Todos os meus livros são simples tentativas de rodear e devassar um pouquinho o mistério cósmico, esta coisa movente, impossível, perturbante, rebelde a qualquer lógica, que é a chamada "realidade", que é a gente mesmo, o mundo, a vida. Antes o obscuro que o óbvio, que o frouxo. Toda lógica contém inevitável dose de mistificação. Toda mistificação contém boa dose de inevitável verdade. Precisamos também do obscuro.

Em geral, quase toda frase minha tem de ser meditada. Quase todas, mesmo as aparentemente curtas, simplórias, comezinhas, trazem em si algo de meditação ou aventura. Às vezes, juntas, as duas coisas: aventura e meditação. Uma pequena dialética religiosa, uma utilização, às vezes, do paradoxo; mas sempre na mesma linha constante, que, felizmente, o Amigo já conhece, pois; mais felizmente ainda, 
somos um pouco parentes, nos planos, que sempre se interseccionam, da poesia e da metafísica. (ROSA; MEYER-CLASON, 2003, p. 238-239).

Importante no conjunto das cartas - creio que compondo a maior parte do material - são as notas referentes às dúvidas de tradução, ou seja, palavras, incluindo os neologismos, e a sintaxe que provocaram dificuldades para o tradutor alemão. Observemos que as notas explicativas selecionadas comprovam a natureza pró-babélica da obra de Guimarães Rosa. Para comprovar tal argumento, selecionei três trechos do conjunto das cartas, em que o próprio autor comenta as suas escolhas, tanto no âmbito do léxico quanto no do sintático:

sebestos: (V. trabalho Paulo Rónai, verbo grego "sebomai" etc. (é um de seus tempos, V. Dicionário grego) Achei curiosa "empastar" o grego (com sentido de "veneração, temor respeitoso", respeito supersticioso), com o coloquial (gíria) brasileiro: "cê besta!" = Você é besta...). (ROSA; MEYER-CLASON, 2003, p. 321).

"no bruaar". Refere-se ao barulho da chuvinha. Tirei do francês (BROUHAHA n. m. (onomat.) Fam. Bruit de voix confus et tumultueux.) Daí, fiz "o bruaá" e "bruaar". Não é bela e sugestiva palavra? (ROSA; MEYER-CLASON, 2003, p. 315).

Vejo: „läuft mir der Mensch über den Weg...“ Não. Aqui deve ser: kommt mir der Mensch in die Quere... (NOTA interessante e IMPORTANTE: quando eu escrevi aquilo ("me atravessa") foi justamente por influência dessa expressão alemã, que eu ouvira muito em Hamburgo (Komm mir nicht in die Quere!), e que sempre achei deliciosa. Como vê, foi verdadeiramente uma "tradução"... do alemão para o português... (ROSA; MEYER-CLASON, 2003, p. 311, grifo nosso). 
Atentemos, em especial, para o procedimento engenhoso descrito por Rosa no terceiro fragmento citado. Ele informa ao tradutor que uma frase que este último traduziu do português para o alemão, originalmente, já havia sido traduzida e utilizada para exprimir o pensamento de um narrador de um romance escrito em português brasileiro e foi, além disso, fruto da experiência linguística do escritor mineiro na própria Alemanha. Rosa, portanto, restitui a tradução frasal ao alemão, retraduzindo para o tradutor uma frase que, se não fosse informada a sua operação tradutória original, chegaria ao alemão de forma indireta, ou seja, como tradução da tradução. Dessa maneira, com um simples comentário como auxílio a seu tradutor, Rosa expõe o mecanismo babélico de sua escrita, bem como nos conscientiza indiretamente de que, em alguns momentos, traduzilo é "traduzir-da-tradução", ou seja, traduzir de uma escrita original já tradutória. Por outro lado, a meu ver, fica evidente que Rosa perdeu a oportunidade de silenciar e deixar que a origem de sua frase seguisse um percurso tradutório mais livre e enigmático, pois, como sabemos, esse muitas vezes é o jogo mais instigante da literatura.

Como radiografia da tradução de Grande sertão: veredas, não posso deixar de citar a carta que considero a mais importante do livro. É uma longa carta de 22 de janeiro de 1964. Ela é uma espécie de balanço da tradução de Clason para o Grande sertão. Aqui podemos vislumbrar o grau de profundidade que Clason dedicou à versão alemã do livro. $\mathrm{O}$ original da carta é em alemão. Na edição brasileira, há a tradução para o português. Num primeiro momento, atentemos para a importância que o tradutor oferece para a questão da tradução cultural, com enfoque para as diferenças temporais e locais envolvidas em tal transposição. Também são interessantes as referências à literatura alemã na busca do tradutor pelo tom e pela caraterização do narrador-personagem do romance na tradução:

Riobaldo fala o alto-alemão. [...] Na Alemanha não há Sertão, não há Nordeste e não conhecemos a "fala 
do matuto”. Seria um equívoco qualquer analogia, ou então tentar traduzir, projetar num dialeto de qualquer região rural da Alemanha, o linguajar infantil, o enlevo lúdico, a mistura inconfundível de familiaridade e desconfiança, de melancolia e arbitrariedade. O seu herói falaria talvez como o Rübezahl, como um carvoeiro da floresta bávara onde tudo ainda deve ser sombrio e original. O leitor apenas riria. Ou então como aquele capitão jagunço criado no século XVIII que Schiller transplantou para a floresta da Boêmia, e que é, no entanto, um aristocrata: Karl Moor com seus bandoleiros? Ou como Simplicissimus que fala a mais vigorosa língua do século XVII? Isto também seria algo reprovável, pois se traduzo "a fé” corretamente por "meine Treue" acabo levando o leitor para o século XVIII e não para um país e uma época onde mesmo o matuto mais primitivo sabe que existe um trem. [...] Riobaldo fala uma língua artificial, um idioma livremente inventado pela pena deste seu criado. Uma coisa, a mais importante, ela tem em comum com o original: o pathos emotivo. (ROSA; MEYER-CLASON, 2003, p. 147).

De certa forma, isso mostra que Clason tem consciência de que a sua tradução “significa não somente 'a passagem' interlingual de um texto, mas - com esta primeira 'passagem' - toda uma série de outras 'passagens' que concerne ao ato" de traduzir (BERMAN, 2007, p. 22).

Mais adiante, ele trata o original como material poético, preocupandose também com a questão da recepção do texto e visando a um leitor que possa se transformar com a leitura literária:

[...] quando captei o que o poeta quis dizer, dei à versão alemã sempre que possível uma forma poética equivalente distanciando-me de uma tradução interpretativa. Toda interpretação mata a poesia à medida que dá mastigado para o leitor o que este 
deveria captar com sua imaginação. (ROSA; MEYERCLASON, 2003, p. 153).

Destaco também um trecho em que há uma preocupação clássica sobre as perdas e os ganhos de uma tradução, com uma concepção de tradução transcriadora, no sentido das reflexões de Haroldo de Campos. Vemos que o tradutor não se percebe mais como uma sombra do original, não sente a si mesmo como escritor servil à sua fonte:

Quem de antemão sabe que trava uma batalha perdida, que luta em desvantagem, para este qualquer achado linguístico é uma vitória. Traduzir Rosa significa: solicitar a ajuda de todas as forças da imaginação; colocar em campo uma tropa inteira de faculdades imaginativas; tentar aqui e acolá pregar uma peça no autor, superar-lhe num ponto e por vezes registrar uma vantagem. [...] tenho de tentar compensar vitórias e derrotas (tanto mais que a cada passo tenho de engolir uma derrota); tenho de juntar numa conta um saldo positivo de versões superiores em alemão para ficar em condições de poder engolir se necessário trechos intraduzíveis ou soluções fracas, até mesmo falhas. [...] tenho de pensar sempre no todo e jamais apenas na frase considerada no momento. [...] minha tradução deveria ser avaliada em bloco, da primeira à última frase composta por duzentas mil palavras, e não com base em amostragens, catadas ociosamente aqui e ali, pois tampouco o original permitiria que depois de algumas páginas alguém dissesse: gosto ou não gosto. Minha versão também é poesia, ou melhor, pretende ser poesia. (ROSA; MEYER-CLASON, 2003, p. 153-154, grifo nosso).

Se original e tradução são poesia, podemos complementar tal reflexão com este belo fragmento de Haroldo de Campos:

O tradutor de poesia é um coreógrafo da dança 
interna das línguas, tendo o sentido (o conteúdo, assim chamado didaticamente) não como meta linear de uma corrida termo a termo, sineta pavloviana da retroalimentação condicionada, mas como bastidor semântico ou cenário pluridesdobrável dessa coreografia móvel. Pulsão dionisíaca, pois dissolve a diamantização apolínea do texto original já préformado numa nova festa sígnica: põe a cristalografia em reebulição de lava. (CAMPOS, 1981, p. 181).

Por fim, uma ousadia do projeto de tradução de Curt Meyer-Clason. No não reconhecimento do original, o tradutor vê a si mesmo como criador:

[...] Onde o Senhor não reconhecer mais o seu texto, foi onde eu provavelmente me saí melhor, pisando sobre o próprio chão, por isso me esforcei sempre para recorrer o mais possível ao "idioma", às expressões idiomáticas e às metáforas. (ROSA; MEYER-CLASON, 2003, p. 159).

O que depreendemos do conjunto de cartas de Guimarães Rosa e Curt Meyer-Clason é uma definição específica de tradução. Para Rosa e Clason, a operação tradutória não se configura como literalidade, pois traduzir literalmente é traduzir palavra por palavra, isto é, uma tradução servil. Nesse sentido, ambos estão próximos de Haroldo de Campos, cuja concepção de tradução de textos criativos "será sempre recriação, ou criação paralela, autônoma porém recíproca”. Para Campos:

Numa tradução dessa natureza, não se traduz apenas o significado, traduz-se o próprio signo, ou seja, sua fisicalidade, sua materialidade mesma (propriedades sonoras, de imagética visual, enfim tudo aquilo que forma [...] a iconicidade do signo estético, entendido por signo icônico aquele "que é de certa maneira similar àquilo que denota"). O significado, o parâmetro semântico, será apenas e tão-somente a baliza demarcatória do lugar da empresa recriadora. 
Está-se pois no avesso da chamada tradução literal. (CAMPOS, 1992, p. 35).

Além disso, depreende-se, na leitura das cartas, que, para autor e tradutor, a tradução literal é uma traição do próprio sentido da arte. Arte e literalidade não se combinam. A tradução literal pode até transmitir uma informação; no entanto, não faz parte dos desígnios de uma obra de arte tradutória informar, pois "o que lhe é essencial não é comunicação, não é enunciado" (BENJAMIN, 2011, p. 102).

Embora o objetivo do texto tenha sido comentar as reflexões sobre tradução contidas na correspondência entre João Guimarães Rosa e Curt Meyer-Clason, gostaria de complementar com uma breve exposição crítica acerca da tradução de Clason de Grande sertão: veredas. Seu conteúdo foi extraído de uma reportagem de uma das edições da revista Piauí de 2012.

Conclui-se das cartas que o tradutor Meyer-Clason tentou preservar três elementos criativos da escrita rosiana: as aliterações, as expressões idiomáticas e os trechos de "elevada poesia". Um exemplo que o autor da reportagem expõe, e que exemplifica a questão poética referida nas cartas, é a frase-verso "feito flecha, feito faca, feito fogo", que se refere, no romance, à descrição dos jagunços galopando. Clason traduziu como wie der Welle, wie der Wille, wie der Wind [como a onda, como a vontade, como o vento]. Como se observa, a tradução não se dá palavra a palavra, mas valoriza a questão sonora, mostrando, por exemplo, como Clason está muito próximo da concepção de tradução de Antoine Berman, que diz que "traduzir a letra de um texto não significa absolutamente traduzir palavra por palavra" (BERMAN, 2007, p. 15).

No nível morfossintático, por exemplo, há a tradução do advérbio "coraçãomente", que Clason verteu como herzherzlich. Ele evitou assim como Rosa dispensou o lugar-comum "cordialmente" - o termo dicionarizado herzlich, recriando a duplicação do escritor brasileiro, a qual provoca um estranhamento no leitor. 
Por sua vez, há também um exemplo em que o tradutor teve de renunciar, em parte, à sua tarefa. Como se sabe, nas páginas iniciais do romance de Rosa, há o clássico desdobramento de vinte e dois nomes para o diabo. No entanto, na tradução para o alemão, o tradutor enumera apenas catorze diabos em forma linguística, como, por exemplo, der Pferdefuss [o pé de cavalo], der Schmutzfink [o sujinho] e der Lügenbold [o mentiroso].

Sobre a questão da tradução de Grande sertão: veredas, não poderia deixar ainda de aludir, mesmo que brevemente, a dois pontos de vista. Um é o do pesquisador Fabio Cecchetto, da Universidade Estadual Paulista, que pesquisou o trabalho de Meyer-Clason. Ele concluiu, em um de seus artigos, que Clason

empalideceu alguns elementos metafísicos do romance e deixou sua polifonia em segundo plano, ao privilegiar uma determinada interpretação em detrimento da riqueza de leituras possíveis no texto de Rosa. Em especial, o sertão apareceu ali como mero cenário da trama, deixando de lado sua dimensão metafórica. (CECCHETTO, 2010 apud ESTEVES, 2012).

Ao estudar o glossário que acompanha a tradução alemã, Cecchetto conclui que Clason deu ênfase a uma "noção de um sertão geograficamente localizado, direcionando o olhar do leitor alemão mais no meio físico, em vez de funcionar como uma alavanca que o impulsiona para dentro do texto" (CECCHETTO, 2010 apud ESTEVES, 2012). Resta saber se essa opção do tradutor não teria sido um entendimento da necessidade estrangeira, naquele momento, de recepcionar a nossa literatura no espaço do folclore - no sentido pejorativo, e não no que temos de complexo e profundo na cultura popular -, e nisso a geografia facilitaria essa recepção. Impulsionar para dentro do texto não seria dizer ao estrangeiro que a nossa literatura é mais do que "folclore", que o romance de Rosa está frente a frente às grandes obras metafísicas universais? No período em que Clason fez a 
tradução para o alemão, será que o mercado editorial alemão e os leitores estavam preparados para essa revelação? Será que eles teriam entendido, por exemplo, que um crepúsculo descrito no sertão muitas vezes era, de fato, um crepúsculo de Hamburgo - cidade onde Rosa morou -, como o próprio autor comenta numa entrevista clássica para a televisão alemã?

Por fim, devemos mencionar o ponto de vista de Berthold Zilly, último tradutor do romance de Rosa. Segundo o próprio Zilly, sua tradução procurou recuperar um elemento que considera ausente na tradução de Clason. Ele diz que "Meyer-Clason tem um domínio fantástico da língua alemã, um estilo bom e bonito" e que "ele produziu um texto muito bem legível, mas a originalidade, a novidade estilística em grande parte se perdeu" (ZILLY apud ESTEVES, 2012). A meu ver, pela leitura detida de suas cartas, inclusive com os vários exemplos dados pelo tradutor - uma genuína oficina de tradução -, não consigo concluir que a tradução de Clason perdeu a originalidade e estilo. No entanto, como se sabe, traduções possuem, em parte, data de validade, e a tarefa de Clason, plasmada na sua tradução, pode ter sido esmaecida com o tempo, precisando de renovação e de novas arcadas tradutórias. Nesse sentido, Walter Benjamin tem razão quando escreve, no ensaio "A tarefa do tradutor", que "enquanto a palavra do poeta perdura em sua língua materna, mesmo a maior tradução está fadada a desaparecer dentro da evolução de sua língua e a soçobrar em sua renovação” (BENJAMIN, 2011, p. 108). Mais ainda, quando se trata de escritos como os de Guimarães Rosa, "quanto mais elevada for a qualidade de uma obra, tanto mais ela permanecerá - mesmo no contato mais fugidio com o seu sentido - ainda traduzível” (BENJAMIN, 2011, p. 118). Na verdade, o próprio Clason, naturalmente, tinha consciência disso, como mostra o fragmento que citei anteriormente (ROSA; MEYER-CLASON, 2003, p. 271-272).

Fiquemos, como último instantâneo, e como homenagem a Clason, com um trecho em alemão de Grande sertão: veredas, a fim de observar 
o estilo e o tom de um fragmento da versão do tradutor, em que, como afirmou o próprio Clason, utilizando analogias musicais, "dependendo do trecho [temos] um andante, um presto, um scherzo ou um furioso" (ROSA; MEYER-CLASON, 2003, p. 161). Na verdade, ele foi escolhido pois foi mencionado em uma das cartas, sendo um fragmento importante, visto que a tradução de Clason é citada já na extensão de um parágrafo. Chamo a atenção para a permanência dos topônimos e antropônimos do original, como se um rio Urucuia sonoro-linguístico cruzasse o rio Reno:

Ich war mit einigen anderen auf eine Hügelkuppe gestiegen, wo der Wind in alle Richtungen blies. Dort konnte der Geist in Horizonte ausgreifen. Und schauen Sie sehen Sie; fünfzehn léguas weit nach der einen Seite lag São Josézinho da Serra, ein blahender Flecken, wo jetzt Nhorinhá wohnte, die Tochter der Ana Duzuza. Wie gesagt, damals wusste ich nichts davon. Erst viel später. Ich hatte auch ihren Brief noch nicht empfangen. Für mich war sie nur eine Sehnsucht, die es zu bewahren galt. So denke ich heute. Die kokette Nhorinhá, die allen zu Willen war, dort wohnte sie, sie war hübsch, ihre Haut hell, und ihre Augen gehörten ihr ganz... Und die Männer stritten sich um ihre Gunst, die besser war als unschuld. Wenn sie also nichts wert war, sie konnte sie dann so vielen Männern lieb und wert sein? (ROSA; MEYERCLASON, 2003, p. 161, grifo nosso).

E a sua prototradução:

Eu, com outros, tinha subido no tope do môrro, que era de espalha-ventos. De lá do alto, a mente minha era poder verificar muitos horizontes. E, mire veja: em quinze léguas para uma bancada, era o São Josezinho da Serra, terra florescida, onde agora estava assistindo Nhorinhá, a filha de Ana Duzuza. Assunto que, na ocasião, meu espírito me negou, digo o dito. Além, além. Dela eu ainda não tinha podido receber a carta 
enviada. Para mim, era só uma saudade a se guardar. Hoje é que penso. Nhorinhá, namorã, que recebia todos, ficava lá, era bonita, era a que era clara, com os olhos tão dela mesma... E os homens, porfiados, gostavam de gozar com essa melhora de inocência. Então, se ela não tinha valia, como é que era de tantos homens? (ROSA; MEYER-CLASON, 2006, p. 519).

\section{Referências}

BENJAMIN, Walter. A tarefa do tradutor. In: BENJAMIN, Walter. Escritos sobre mito e linguagem. Organização, apresentação e notas de Jeanne Marie Gagnebin. Tradução de Susana Kampff Lages e Ernani Chaves. São Paulo: Duas Cidades; Editora 34, 2011. p. 101-119.

BERMAN, Antoine. Introdução. In: . A tradução e a letra: ou o albergue do longínquo. Tradução de Marie-Hélène C. Torres, Mauri Furlan e Andréia Guerini. Rio de Janeiro: 7 letras, 2007. p. 15-24.

CAMPOS, Haroldo de. Post scriptum: transluciferação mefistofáustica. In: CAMPOS, Haroldo de. Deus e o Diabo no Fausto de Goethe. São Paulo: Perspectiva, 1981. p. 179-209.

CAMPOS, Haroldo de. Da tradução como criação e como crítica. In: CAMPOS, Haroldo de. Metalinguagem e outras metas. São Paulo: Perspectiva, 1992. p. 31-48.

ESTEVES, Bernardo. O jagunço de Munique. Piauí, Rio de Janeiro, ano 6, n. 67, abr. 2012. Disponível em: https://piaui.folha.uol.com.br/materia/o-jagunco-de-munique/. Acesso em: 22 nov. 2021.

MARTINS, Nilce Sant'Anna. O léxico de Guimarães Rosa. 3. ed. São Paulo: Edusp, 2021.

MEIGUINS, Alessandro. O universo de Guimarães Rosa. Revista Vida 
Simples, n. 38, p. 39-51, fev. 2006.

ROSA, João Guimarães; MEYER-CLASON, Curt. João Guimarães Rosa: correspondência com seu tradutor alemão Curt Meyer-Clason (19581967). Edição, organização e notas de Maria Apparecida Faria Marcondes Bussolotti. Tradução de Erlon José Paschoal. Rio de Janeiro: Nova Fronteira: Academia Brasileira de Letras; Belo Horizonte: Ed. da UFMG, 2003.

ROSA, João Guimarães. Grande sertão: veredas. 1. ed. Rio de Janeiro: Nova Fronteira, 2006. (Biblioteca do Estudante).

Translate-from-iranslaiton: from Urucuia to Rhine, from Rhine to Urucuia

Abstract: This article analyses the correspondence between Brazilian author João Guimarães Rosa and his first German translator, Curt Meyer-Clason, especially the translation and language conception of both letter writers. Furthermore, there are some quotes from translation theorists like Walter Benjamin, Haroldo de Campos and Antoine Berman. Lastly, the text provides commentaries on MeyerClason solutions to the translation of Rosa's fiction into German, from lexical examples to an excert in paragraph form.

Keywords: Letter. Translation. German. Guimarães Rosa. Curt Meyer-Clason.

Recebido em: 24/02/2021

Aceito em: 22/10/2021 